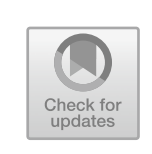

\title{
France: Credit Control and Formalization of Banking Supervision
}

\subsection{INTRODUCTION}

The character of the French financial system during 1945-1984 was seen as (semi-)publicness. Large financial institutions have been nationalized by the government, and official control power was relatively strong over the activities of commercial banks. Banking supervision was not regarded as a mere prudential measure but also as an indirect control tool of the economy (economic growth, inflation rate, etc.), an essential policy field in the post-war era. Indeed, the role of French supervisory agencies-the Banking Control Commission (Commission de contrôle des banques, CCB), which was part of the central bank (Banque de France)was submitted to larger objectives: to mitigate and stabilize the inflation rate and, more importantly, to steer credit to priority economic activities. Previous literature (in English) which detailed the prudential aspect of the Banking Control Commission is very scarce at the moment. A stronger focus has been recently placed on the monetary and credit policy of the Banque de France and its role in stabilizing inflation (Monnet 2018).

By focusing in this chapter on the micro-prudential aspect of Banking Control Commission, which changed its name to Banking Commission (Commission Bancaire) in 1984, we traced the formalization of banking supervision with the following questions in mind: was the formalization process caused by necessity of control or by coping with a financial crisis; what was the role of the CCB in the purpose of financial stability or mere

(C) The Author(s) 2022

E. Hotori et al., Formalization of Banking Supervision, https://doi.org/10.1007/978-981-16-6783-1_8 
credit control; how come France adopted a formalized supervisory regime only in the 1940s?

In addition, this chapter includes an account of the supervisory regime before the Act of 1941, since recent research suggests that the financial crisis of the 1930s had a much more significant impact on French banks than the literature had so far acknowledged (Baubeau et al. 2021).

\subsection{Overview of French Banking System}

The French banking system, as it developed during the twentieth century, takes its roots in the evolution of the nineteenth century, and has been a mixture of "liberal moods" and public ownership. From the midnineteenth century onwards, systemically important banks were established in France in conjunction with public paid-in capital (Des Essars 1896). In 1848, Discount Bank of Paris (Comptoir d'Escompte de Paris) was established with two-thirds capital paid by the State and the city of Paris. It is considered one of the earliest bank created as a joint-stock company. However, the Discount Bank of Paris, as well as other Comptoirs d'escompte were soon fully privatized, by an imperial decree in 1853. Later, in 1889, the bank changed its name to Comptoir National d'Escompte de Paris after a severe crisis and a liquidation. Other large joint-stock banks were established during the same period: the Crédit Industriel et Commercial in 1859, the Crédit Lyonnais in 1863, and the Société Générale in 1864 (Germain-Martin 1954). Those three institutions eventually developed into the main pillars of French deposit banking. During the second half of the nineteenth century, deposit banks also became more and more active on the stock exchange-issuing bonds, underwriting securities, etc. (Quennouëlle-Corre 2011). As opposed to those successful enterprises, the nineteenth century also witnessed significant setbacks in the evolution of commercial banking: the failures of the Credit mobilier (1852-1867), the Union Générale (1875-1882) are well-known examples.

In addition to the large commercial banks who gradually specialized in deposit banking, the French financial system featured significant banques d'affaires (investment banks or merchant banks). The Banque de Paris et des Pays-Bas (founded in 1872), the Banque de l'Union parisienne (founded in 1904) were its most famous representatives (Cassis 2010: 103-104). They specialized in long-term investments as well as bond issuance, and were very active on foreign markets. Asides from the 
large commercial banks and the merchants banks, the French financial system also included other actors, such as banks specialized in agricultural credit (the 1852 established Mortgage Bank of France-Crédit Foncier de France-a central agency for land credit businesses with a subvention from the State), and the Haute Banque (private bankers). The private banking houses, in particular the Rothschild Frères, despite the growing development of joint-stock banks, remained major stakeholders on the French financial market.

By the early twentieth century, the French banking system was composed of the private banks, i.e., so-called haute banque (private bankers-e.g., Rothschild), joint-stock banks (banques d'affaires-investment banks-and deposit banks) - e.g., Paribas and the Crédit Lyonnais-savings banks, cooperative specialized banks (e.g., Banques populaires, Crédit Agricole) and long- and medium-term credit banks (e.g., Crédit National, Crédit Foncier). A few foreign institutions were also present in Paris: banks from the UK, Germany, and the US (Bonin 2005).

From 1913 to 1938 , the French banking industry was influenced by the growth of a semi-public sector (Quennouëlle-Corre and Straus 2010: 103-105). However, the large commercial banks continued to dominate the French financial market during the 1920s. In the early 1930s, during the Great Depression, several large deposit banks were close to failure, and those were rescued and merged with other banks. Indeed, the global financial crisis had a significant impact on French banks (Baubeau et al. 2021). A severe credit crunch affected them, with a movement of deposits away from banks toward savings institutions and the central bank. Between October 1930 and early 1932, France witnessed two waves of banking failures, which only affected the large commercial banks indirectly. The second largest investment bank, Banque de l'Union Parisienne was on the edge of the collapse in 1932-1934, yet the bank was rescued by the central bank (Banque de France).

Although France experienced a severe financial crisis during the early 1930s, neither financial regulation nor equity control was in a first phase introduced into French banking system. The reason is presumed that the four large commercial banks with approximately $50 \%$ share of total deposits did not suffer serious damage from the crises. Especially, Crédit Lyonnais increased amount of deposits and replaced the role of failed banks in lending business (Baubeau et al. 2021: 244). Despite the massive credit crunch that resulted from a series of major banking panics, it was not until 1941 that state interventionism prevailed under 
the Vichy regime. The incorrect narrative that France had not been affected by a banking crisis during the early 1930s, was even used in 1936 as an argument in the political debate to avoid implementing banking regulations.

Thus, the French banking system adopted specialized lines: deposit banks and investment banks on one side, and more specialized institutions (agriculture banks, savings banks, and long-term lending banks) on the other side.

\subsection{EMERGENCE OF Rigid Commercial Banking Regulation}

Although France experienced financial crises during the second half of the nineteenth century and during the Great Depression of the early 1930s, formal regulation on commercial banking was not adopted before 1941 (Creel et al. 2012: 12-13).

The development of the 1941 Banking Act has been studied in depth by historian Claire Andrieu. The law that was adopted in 1941 was actually endorsed by the same groups who had successfully opposed it in 1936-1938. This remarkable turnaround is most emblematically personified by Henri Ardant (1892-1959), CEO of the Société Générale, who opposed the regulation of banks before the war, but was elected in 1941 at the head of the Committee representing the banks in the newly organized system. This historic turn of events was due to the change of regime. The establishment of an authoritarian State, combined with foreign occupation, made this remarkable turnaround possible. Banking, as other sectors of the economy, was affected by significant structural changes in the wake of Vichy dirigisme and the ideology of national revolution (Margairaz 2009). The reform was rather radical and marked a break in the history of French banking, because it fueled the banks under the more or less direct control of the state and a corporatist organization. The interests of the banks were grouped and represented by the Comité d'organisation des banques; this committee, in which the major banks were prominent, had significant powers. It could for example refuse the membership of a company to the list of official banks (Andrieu 1990: chap. 7). In a few years (1940-1945) a full-fledged reform was achieved, in two directions: the control of the entire banking sector was established, and the nationalization of four commercial banks and the Banque de France was carried out (Andrieu 1990: 38-119). 
Indeed, the first Banking Act (Vichy Act) was enacted on 13 June 1941, yet the main intention of the Act was to control credit after abolishment of the gold standard. The following two banking agencies, in a dualist system, were organized under the Act of 1941 (Andrieu 1990: 207-208). The Standing Committee of Banks (Comité d'Organisation permanent des Banques) consisted of six bankers and a government representative was the agency to regulate the whole banking system. It was designed as a corporatist commission, with a direct representation of the supervised sector, had regulatory powers and set entry requirements. The Banking Control Commission (Commission de Contrôle des Banques), on the other hand, was the agency for enforcement of the bank regulations (Beduc et al. 1992: 256-257). It was dominated by the central bank (Banque de France), and its main activity was to check the accounting of banks. The Act of 1941 contained several provisions of prudential regulation-minimum capital of banks, standard formulas of periodic situations and of profit and loss accounts. What is more, in 1941, the concept of registered bank was introduced. For the first time in French history, a legal definition of banking was introduced, and the first census of banks was conducted.

After the Second World War, on 2 December 1945, the second banking Act was implemented. In terms of supervision, it endorsed the same principles as the 1941 law, yet in a different spirit. Its main innovation was the nationalization of banks (Chambost and Touchelay 2021). Under the Act, the four largest commercial banks (Crédit Lyonnais, Société Générale, Comptoir National d'Escompte de Paris, and the Banque nationale pour le commerce et l'industrie) and Banque de France were nationalized to control lending and support a quick recovery of economy (Plessis 2003: 6-7). Furthermore, financial institutions were compartmentalized into four categories: deposit banks, investment banks and medium- and long-term lending banks, and banks with special legal status (such as Crédit Agricole) (Thiveaud 1997). This separation of banking business was similar to that of the Glass-Steagall Act of 1933 in the US. At the same time, the Act of 1945 upheld the essential elements of regulation in the Act of 1941. Minimum capital regulation was set at 5,000,000 francs for joint-stock banks and at 1,000,000 francs for partnership/personal banks. The standard formulas of periodic situations, balance sheets, and profit and loss accounts were established.

The Standing Committee of Banks (Comité d'organisation professionelle des banques), which was ideologically marked by the authoritarian 
and corporatist Vichy regime, was replaced by the National Credit Council (Conseil National du Crédit). The professional representation lost its official powers for the benefit of Finance Ministry and central bank's delegates. The National Credit Council's essential role was to approve the Ministry's and central bank's decisions (Andrieu 1990: 242). However, a professional organization of bankers, the Association professionnelle des banques, now renamed Association française des banques, remained.

Despite those institutional differences, there was a strong continuity between the 1941 and 1945 Acts. French banking regulation switched the character of banking system from semi-corporatism to state interventionism (Margairaz 2016). Under the Act of 1945, competition among banks reduced significantly. The major concern of the government was to separate the banks from the risk of instability stemming from competition and to ensure financing for reconstruction. Thus, the banks hardly increased their number of branches from 1945 to 1959. From 1948 on, a quantitative credit control was established: the credit system became an administered system by the Banque de France rather than regulated by the market (Margairaz 1991).

The "Debré laws" of 1966/1967 reduced the distinction between the investment banks and the deposit banks. The banks began to offer various sorts of financial instruments-personal loans, mutual funds, etc. The deposit banks were also authorized to open a new branch at will, which led to an increased number of branches. Michel Debré arranged the amalgamation between the C.N.E.P. and B.N.C.I, which resulted in the birth of the largest French Bank, B.N.P. (Banque Nationale de Paris), achieved in 1969. During the 1970s, the large national deposit banks witnessed a return of tighter credit restrictions, which became both a monetary and supervisory policy instrument (Mastin 2020a). Since the 1960s, credit restrictions which limited the growth of volume of loans for each bank had been implemented, notably to fight inflation. Yet, commercial banks reacted to the renewed constraints by engaging in window dressing and illicit credit transfers. This market of unrestricted loans occurred partly beyond the control of the monetary authorities, which tried to regulate it (Monnet 2018).

However, the banking sector was still regulated and compartmentalized. It was not until the Banking Law of 1984 that all banks were subject to the same set of rules under waves of financial deregulation. In addition, privatization of major banks took place in 1987 for Société 
Générale, Crédit Commercial de France, Paribas and Suez, in 1988 for Caisse Nationale de Crédit Agricole, and in 1993 for B.N.P. (Plessis 2003: 7-8). The banking reforms of the 1980s, which included a gradual removal of the credit restrictions, initiated by socialist leaders, paved the way for future financial deregulation and less state interventionism that would prevail in the 1990s (Cassou 2016; Quennouëlle-Corre 2018; Kaspereit 2020).

\subsection{BANKing Control Commission As a Supervisory Agency}

As aforementioned, the banking supervisory agency, the Banking Control Commission, was organized in 1941 in France. The Commission was mainly ${ }^{1}$ composed of the Governor of the Banque de France (as chairman), the Director of the Treasury, and the Chairman of the Committee Permanent Professional Organization of Banks. The Commission was empowered to implement supervision and to control banks together with regulatory powers, jurisdictional powers, and special powers concerning the verification of nationalized deposit banks-which, moreover, were under the direct control of the Minister of Finance. However, the semi-public or cooperative banks (e.g., Crédit Agricole and savings banks) were directly supervised by the Ministry of Finance and remained outside of the scope of the BCC. Following the Act of 1945, the members of the Commission were expanded to the President, the President of the Finance Section of the State Council, the director in charge of credit matters at the Ministry of National Economy, a bank representative appointed by the Ministry of Finance (nominated by the Professional Association of Banks), and a representative of the bank staff appointed by the Minister of Finance (Fournier 1951: 591-599; Quennouëlle-Corre and Straus 2010: 107-108). This change was a simple reflection of the demise and exclusion of the Standing Committee of Banks, whose delegates were replaced by the Ministry of Finance and Banque de France representatives.

Enforcement activities came to be fully effective after the Act of 1945, together with the decision on 19 January 1944. For its own use, the

\footnotetext{
${ }^{1}$ In this chapter, banking supervision for colonial countries (e.g., Algeria) is excluded.
} 
Commission was empowered to require more detailed quarterly situations of a bank in addition to standard forms of annual balance sheet and profit and loss accounts. In response to the proposal of the Banque de France, the Decrees of 28 May 1946 provided that the Commission was given a discretionary power to amend regulation regarding bank management manner to ensure/maintain banks' solvency and liquidity. Beyond their formal adoption, it is uncertain whether the ratios were enforced. In addition to liquidity ratio and solvency ratio, total amount of credits to the same person/company should be reported in the risk division report to another department of the Banque de France, the Centrale des risques. By the decision on 11 February 1948, the Commission imposed $60 \%$ of minimum liquidity ratio on the deposit banks. ${ }^{2}$ During a first period (1945-1957), the liquidity supervision was exercised indirectly through liquidity control (Treasury bill floor and rediscount ceiling); this was followed by a period of direct quantitative control (credit restrictions, first temporary, then permanent from 1972 onwards) (Mastin 2020 b). Furthermore, the liquidity requirements were de facto met with the almost automatic refinancing by the Banque de France.

The Commission-constituting a Tribunal Administratif-was given a strong power to charge the following penalties without prejudice; warning, censure, prohibition/limitation of certain operations (for example, the lowering of the rediscount ceiling until 1972), suspension of responsible managers (with nomination of a provisional administrator), and revocation of bank license (the last power has "never been exercised"). In addition, the Commission (and/or the Association Française des Banques) organized a Tribunal Repressif, and it could impose punitive sanctions (e.g., fines and imprisonment) for breaches of the articles of the Act of 1941 (Welch 1981: 78-79).

Until the Banking Act of 1984, the role of the Commission (supervisory agency) was primarily to prevent any failures of banks and to enforce credit regulations. In the post-war French setup focused on the domestic national banking system, the credit restrictions also served the purposes of the exchange control. In this perspective, the administered system primarily sought to meet the objectives designed by the governmental Plan commission: investments, exports, and housing were targeted as preferential sectors that benefitted from privileged credit conditions.

\footnotetext{
${ }^{2}$ Due to the post-war rapid inflation, the Commission suspended solvency ratio regulation and risk division ratio regulation.
} 
With regard to its disciplinary toolbox, the Commission shared the power, together with the National Credit Council or the Professional Association of Banks, to prosecute the offenses in common law courts. Especially, the power of qualifying a bank, a credit institution, or a banker in a public document was an effective "weapon" to prevent breaches of the laws in force. In addition, the Commission was empowered to appoint a provisional administrator with all the powers of administration, management, and direction whenever misconduct of a director of a bank or a financial institution was found (Fournier 1951: 597-599). Despite those formally significant powers, several obstacles to an effective enforcement of the supervisory measures remained. For example, the growing size of the networks (branches, subsidiaries, etc.) and the heterogeneity of the accounting systems impeded a thorough audit by the Banque de France inspectors (who audited on behalf of the BCC).

Apparently, authorities over bank personnel issues and powers of licensing were essential source for actual enforcement activities of banking supervisor. In practice, the Commission conducted about 60 numbers of on-site bank examination (on-the-spot inspections) - each bank was inspected every five or six years (Welch 1981: 64-65).

$$
* * *
$$

The banking supervision in France was formalized under the Banking Act of 1941 and of 1945. The law adopted in 1941 was endorsed by the same groups who had been against it during 1936-1938. Hence, the Act of 1941 intended to control over the credit in the country as well as to stabilize national economy after abolishing the gold standard. In 1941 the Banking Control Commission as the supervisory agency was created, and rigid financial regulation such as a minimum capital requirement was introduced.

After Liberation, the Banking Act of 1945 can be seen as implementation of the formal banking supervision in France. The essential contents (supervisory organization and bank regulation) of the 1941 Act were upheld. Not only separation of banking business and nationalization of large banks but also introduction of a set of bank regulation resulted in less competition among banks in France. However, less competition was favorable for French government since control of credit toward quick recovery was the top priority in economic policy at that time. The supervisory agency was given a lot of measures to enforce bank regulation. 
Authorization of rigid penalties (e.g., a right to replace a misconducting bank manager) enhanced effectiveness of supervisory activities. Therefore, the French banking supervision more or less included prudential function aside from the order of priority over its activities.

The driver of formalization in French case can be summarized as control of credit for the purpose of stabilization of national economy as well as quick reconstruction following Liberation.

\section{REFERENCES}

Andrieu, C. 1990. La banque sous l'occupation: paradoxes de l'histoire d'une profession 1936-1946. Paris: Presses de Sciences Po.

Baubeau, P., E. Monnet, A. Riva, and S. Ungaro. 2021. Flight-to-safety and the credit crunch: A new history of the banking crisis in France during the Great Depression. Economic History Review 74 (1): 223-250.

Beduc, L., F. Ducruezet, and P. P. Stephanopoli. 1992. The French financial system. In Banking structures in major countries, ed. C. G. Kaufman. Boston: Kluwer Academic Publishers.

Bonin, H. 2005. The challenged competitiveness of the Paris banking and finance markets, 1914-1958. In London and Paris as international financial centres in the twentieth century, ed. E. Bussiere and Y. Cassis, 183-204. Oxford: Oxford University Press.

Cassis, Y. 2010. Capitals of capital: The rise and fall of international financial centres, 1780-2009. Cambridge: Cambridge University Press.

Cassou, P.-H. 2016. La réglementation bancaire, entre intérêt général et intérêts particuliers. In Crises et régulation bancaires. Les cheminements de l'instabilité et de la stabilité bancaires, ed. H. Bonin and J.-M. Figuet, 243-269. Genève: Droz.

Chambost, I., and B. Touchelay. 2021. Quand l'État devient banquier. Revue de la régulation. Capitalisme, institutions, pouvoirs 30 (1): 1-18.

Creel, J., Le Cacheux, J., and M. Viennot. 2012. The French financial system since 1980. In The French financial system, from past to present, ed. C. Blot, J. Creel, A. L. Delatte, K. Durand, A. Gallois, P. Hubert, J. Le Cacheux, S. Levasseur, and M. Viennot. FESSUD Studies in Financial Systems 2.

Des Essars, P. 1896. Banking in France. In A history of banking in all the leading nations, ed. W. G. Sumner, 101-128. New York: Augustus M. Kelly (reprinted in 1971).

Fournier, H. 1951. La Commission de Contrôle des Banques. Revue économique 2 (5): 591-599

Germain-Martin, H. 1954. France. In Banking systems, ed. B. H. Beckhart, 225310. New York: Columbia University Press. 
Kaspereit, A. 2020. La loi bancaire du 24 janvier 1984: à la croisée des réformes. In Pour une histoire sociale et politique de l'économie: hommages à Michel Margairaz, ed. D. Fraboulet and P. Verheyde, 167-180. Paris: Éditions de la Sorbonne.

Margairaz, M. 1991. L'État, les finances et l'économie. Histoire d'une conversion 1932-1952. Paris: Comité pour l'Histoire Economique et Financière de la France

- 2009. Les politiques économiques sous et de Vichy. Histoire et Politique 9 (3) 93-112.

. 2016. La période singulière où la banque de France s'est nationalisée (1936-1966): De l'imbrication dans la politique nationale du crédit à la tentation de la politique monétaire. In Les banques centrales et l'État-nation, 395-450. Paris: Presses de Sciences Po.

Mastin, J.-L. 2020a. Encadrement du crédit et contrôle bancaire dans les années 1970 : la résistance des banques nationales (1968-1980), L'exemple de la Société Générale. Histoire, economie societe 39 (2): 101-126.

. 2020b. La résistance des banques nationales au contrôle du crédit (19501970): L'exemple de la Société Générale. In Pour une histoire sociale et politique de l'économie: hommages à Michel Margairaz, ed. D. Fraboulet and P. Verheyde, 151-166. Paris: Éditions de la Sorbonne.

Monnet, E. 2018. Controlling credit: Central banking and the planned economy in postwar France, 1948-1973. Cambridge: Cambridge University Press.

Quennouëlle-Corre, L., and A. Straus. 2010. The state in the French financial system during the twentieth century: A specific case? In State and financial systems in Europe and the USA, ed. S. Battilossi and J. Reis, 97-121. Farnham: Ashgate.

Quennouëlle-Corre, L. 2011. The decline of Paris as an international financial centre 1914-1940. In Financial centres and international capital flows in the nineteenth and twentieth centuries, ed. L. Quennouëlle-Corre and Y. Cassis, 179-196. Oxford: Oxford University Press.

- 2018. Les réformes financières de 1982 à 1985: Un grand saut libéral? Vingtieme Siecle, Revue d'histoire 138 (2): 65-78.

Plessis, A. 2003. The history of banks in France. Cheltenham: European Association for Banking History (EABH) and Edward Elgar Publishing.

Thiveaud, J.-M. 1997. Les évolutions du système bancaire français de l'entredeux-guerres à nos jours: Spécialisation, déspécialisation, concentration, concurrence. Revue d'économie financière 39 (1): 27-74.

Welch, J., ed. 1981. The regulation of banks in the members states of the EEC. Hague: Martinus Nijhoff Publishers. 
Open Access This chapter is licensed under the terms of the Creative Commons Attribution 4.0 International License (http://creativecommons.org/licenses/ by $/ 4.0 /$ ), which permits use, sharing, adaptation, distribution and reproduction in any medium or format, as long as you give appropriate credit to the original author(s) and the source, provide a link to the Creative Commons license and indicate if changes were made.

The images or other third party material in this chapter are included in the chapter's Creative Commons license, unless indicated otherwise in a credit line to the material. If material is not included in the chapter's Creative Commons license and your intended use is not permitted by statutory regulation or exceeds the permitted use, you will need to obtain permission directly from the copyright holder.

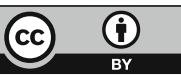

